University of Wollongong

Research Online

Faculty of Law, Humanities and the Arts Papers (Archive)

Faculty of Arts, Social Sciences \& Humanities

$1-1-2012$

Signature and illusion: lessons from the baroque for 'truth' in law, arts and humanities

Richard Mohr

University of Wollongong, rmohr@uow.edu.au

Follow this and additional works at: https://ro.uow.edu.au/lhapapers

Part of the Arts and Humanities Commons, and the Law Commons

Research Online is the open access institutional repository for the University of Wollongong. For further information contact the UOW Library: research-pubs@uow.edu.au 


\title{
Signature and illusion: lessons from the baroque for 'truth' in law, arts and humanities
}

\author{
Abstract \\ Basic to contemporary problems in the disciplines of representation and interpretation is a split between \\ a naïve acceptance of bare facts, presumed to exist in their own 'objective' world of objects, and the \\ actions of subjects who interpret an intersubjective world. The solution is sought in some 'new' \\ epistemologies: Martín Alcoff, Grosz, Kristeva, Butler, as well as in Benjamin and Gadamer, who look back \\ to older ways of knowing. The methodology is an archaeology of these ways of knowing, focussed on a \\ crucial transition in the understanding of representation between the renaissance and the baroque. It \\ uses quintessential methods of the humanities: narrative, keywords and critique. The narrative tracks two \\ keywords of the sixteenth and seventeenth centuries, signature and illusion (inganno), through their uses \\ in renaissance science and baroque arts and philosophy. Following the enlightenment split between the \\ understanding of the arts or humanities and sciences, the keywords re-emerge in familiar contemporary \\ legal forms: the signature as an efficacious performative; illusion as ideology and repression. The truth in \\ law, as in the arts and humanities, is built up from interrogation of representations, prior understanding, \\ and comprehension of human motivation. For this it needs a hermeneutics based in tradition and \\ memory. Since representations and interpretations can be vehicles for rationalisation and repression, \\ there is also need for a critical hermeneutics, which may find truth in unexpected places, such as the \\ repressed memory uncovered in an old ritual or image.
}

\section{Keywords}

baroque, truth, law, arts, humanities, illusion, signature, lessons

\section{Disciplines}

Arts and Humanities | Law

\section{Publication Details}

Mohr, R. (2012). Signature and illusion: lessons from the baroque for 'truth' in law, arts and humanities. The Australian Feminist Law Journal, 36 (June), 45-63. 


\title{
SIGNATURE AND ILLUSION: LESSONS FROM THE BAROQUE FOR 'TRUTH' IN LAW, ARTS AND HUMANITIES
}

\begin{abstract}
Richard Mohr*
Abstract. Basic to contemporary problems in the disciplines of representation and interpretation is a split between a naive acceptance of bare facts, presumed to exist in their own 'objective' world of objects, and the actions of subjects who interpret an intersubjective world. The solution is sought in some 'new' epistemologies: Martín Alcoff, Grosz, Kristeva, Butler, as well as in Benjamin and Gadamer, who look back to older ways of knowing. The methodology is an archaeology of these ways of knowing, focussed on a crucial transition in the understanding of representation between the renaissance and the baroque. It uses quintessential methods of the humanities: narrative, keywords and critique. The narrative tracks two keywords of the sixteenth and seventeenth centuries, signature and illusion (inganno), through their uses in renaissance science and baroque arts and philosophy. Following the enlightenment split between the understanding of the arts or humanities and sciences, the keywords re-emerge in familiar contemporary legal forms: the signature as an efficacious performative; illusion as ideology and repression. The truth in law, as in the arts and humanities, is built up from interrogation of representations, prior understanding, and comprehension of human motivation. For this it needs a hermeneutics based in tradition and memory. Since representations and interpretations can be vehicles for rationalisation and repression, there is also need for a critical hermeneutics, which may find truth in unexpected places, such as the repressed memory uncovered in an old ritual or image.
\end{abstract}

\subsection{INTRODUCTION}

New interest in 'the humanities', particularly from scholars of law, has many manifestations and a number of sources. It can be seen in initiatives such as two new journals on law and humanities started in 2005 and 2007 in the USA and UK respectively, in the recent establishment of the Australian Consortium of Humanities Research Centres (ACHRC), or in Martha Nussbaum's work on the importance of the humanities (which followed her work on 'humanity' and the law). ${ }^{1}$ Among the sources of this interest appear to be both push and pull factors.

* Director, Social Research Policy \& Planning, and Visiting Professorial Fellow in the Legal Intersections Research Centre, Faculty of Law, University of Wollongong.rmohr@srpp.com.au. A version of this paper was given as the keynote address to the International Conference on Arts, Ideas and the Baroque, at the 9th Montreal Baroque Festival, 'Péchés capiteaux'. 24-25 June 2011. The author acknowledges the generous support and encouragement of Professor Desmond Manderson and Dr Leigh Yetter, Institute for the Public Life of Arts and Ideas, McGill University, Montreal.

1 Nussbaum Martha C. Not for Profit: Why Democracy Needs the Humanities Princeton University Press Princeton 2010; Nussbaum Martha C. Hiding from Humanity: Disgust, Shame and the Law Princeton University Press Princeton 2004 
On one hand, there is the threat posed by a certain neglect of knowledge and of disciplines that do not feed directly in to 'economic' pursuits. The arts and humanities are '[s]een by policymakers as useless frills at a time when nations must cut away all useless things in order to stay competitive in the global market'. ${ }^{2}$ It is a theme that has rapidly come to the fore in the UK with the 2010 report of the Browne review to the Conservative government, which suggests an end to subsidies for all courses except medicine, science, engineering and modern languages. ${ }^{3}$ Disciplines that are not oriented to technology or the economy feel threatened and are drawing up the wagons around a common area that is called, in an almost residual sense, 'humanities'.

On the more positive side, there is a broadening of perspectives. After 'law and society', 'law and literature', critical legal studies and the rapid expansion in the late twentieth century of cultural studies ${ }^{4}$, it has seemed increasingly artificial to put interdisciplinary studies of law and legal phenomena into such silos. Interdisciplinarity and an impatience with artificial boundaries are also characteristic of the broader humanities 'movement', exemplified in the interests and discussions among members of the ACHRC. In legal studies and the humanities there is a sense that the streams have converged and we can begin to discern the outlines of a fine river.

From this quick description of recent moves in law and the humanities, we can see both exclusive and inclusive forces. Humanities is not science, not technology. It is a concern with a wide range of pursuits including arts, history, culture, ideas and media. Moreover, it takes a particular interest in the connections between those areas. In trying to define our areas of interest in law and the humanities it is important to keep these common understandings in mind, while at the same time seeking a better understanding of the foundations and strengths of the humanities, particularly at their interface with legal phenomena.

Law and the humanities focus on human cultural products, including art and media as well as texts such as legal, historical and literary documents. The need for interpretation is common to all of these interests. In what follows I explore the nature of interpretation and its role in the humanities and culture. My intention is to explore some common methodological foundations for the humanities. This is an epistemological program, asking the question: how do we know? Because it is not divorced from practice (whether scholarship or social, cultural or legal practice), it also has an ontological dimension, which refers to the conditions of social life and practice: how do we live (together)?

This article begins by identifying contemporary problems in the disciplines of representation and interpretation. Basic to these is a split between a naïve acceptance of bare facts, presumed to exist in their own 'objective' world of objects, and the actions of subjects who

\footnotetext{
As above (2010) at 2.

Shepherd Jessica. 2010. 'Browne review: Universities warned to expect $£$ 4.2bn cuts’ The Guardian. 15 October 2010. http://www.guardian.co.uk/education/2010/oct/15/browne-review-universities-cuts?INTCMP=ILCNETTXT3487 accessed 30 January 2012.

4 This 'cultural turn' has been echoed in a 'spatial turn' and a 'pictorial turn'. The latter is of particular relevance to the rediscovery of the baroque and the subject matter of this article. See for example Delaney David 'Semantic Ecology and Lexical Violence: Nature at the Limits of Law' (2001) 52 Law Text Culture 77-112; Hess-Lüttuch Ernst W. B. 'Spatial Turn: On the Concept of Space in Cultural Geography and Literary Theory' (2011) 9-10 Lexia 23-42 and, on the 'pictorial turn', chapter 1, of that name, in Mitchell W J T Picture Theory. Essays on Verbal and Visual Representation University of Chicago Press Chicago 1994
} 
interpret an intersubjective world. The problem is illustrated by instances of deception in politics and misconceptions of law. The solution is sought in some 'new' epistemologies, of recent feminists as well as Walter Benjamin and Hans-Georg Gadamer, which look back to older ways of knowing. To unearth the archaeology of these ways of knowing, I go back to a crucial transition in the understanding of representation between the renaissance and the baroque.

My methodological process is an exercise in showing by doing. In seeking to elucidate the foundations of the humanities, I plan to use quintessential methods of the humanities: narrative, keywords and critique. My narrative is based on the historical trajectory of two keywords of the sixteenth and seventeenth centuries: signatura and inganno; signature and delusion. ${ }^{5}$ At the first appearance of these keywords, their original meanings and uses are explained. The narrative resumes to trace their fortunes, through the changing understanding of the uses of representation, and the divergent epistemological foundations of the sciences and the arts. Between the shores of object and subject, sundered by the enlightenment, the humanities were left isolated in the torrent. In conclusion the keywords re-emerge in familiar contemporary legal forms: the signature as an efficacious performative; delusion as ideology and repression. In these guises they have offered new direction for research in law and the humanities, in exploring the interactions between subjects and objects, people and things, power and pictures.

Seeing these key concepts through the fresh eyes of the baroque opens new possibilities for understanding and critique. The signature, as a legal performative, really does change the civil world. Games of illusion once again reveal truths in art and the power of dreams. The baroque discovered not only that appearances may deceive, but that they may be used to deceive. Representations, as 'entities that don't sleep', are the stuff of social power. Without them our social interactions would be ephemeral, a social order rebuilt every morning, as in Serres's 'unstable band of baboons [where] social changes are flaring up every minute'. ${ }^{6}$ We rely on concrete representations, embodied in objects, in law and all other practices of the social order. We also need an informed scepticism, a 'hermeneutics of suspicion', that allows us to decode the repressive languages of power and to distinguish the truth, in art, law or politics, from the deception.

\subsection{Practical Problems-Epistemological Solutions?}

Law and the humanities are both based on representation and interpretation. They conjure images, combine words and inquire into the meanings and uses of those constellations. These activities are neglected in many areas of scholarship and public life, replaced by a naïve

5 In what follows I will generally prefer the Italian word inganno or the Spanish equivalent engaño, since they carry a deeper meaning than 'delusion' or 'illusion' and imply trickery, as does the French trompe. I hope their meaning will be explicated by reference to primary sources in Italian and in Spanish.

6 Serres Michel Genesis University of Michigan Press Ann Arbor 1995 at 87 . The example has been elaborated by Latour and Strum: see Latour Bruno Reassembling the Social: An introduction to Actor-Network-Theory Oxford University Press Oxford 2005 at $69-70$. 
empiricism: 'WYSIWYG' - 'what you see is what you get' - in the jargon of the dotcom decade; 'facts' ('not assertions'), to quote Colin Powell's description of the grainy images he showed the United Nations on 3rd February 2003 to justify the invasion of Iraq. ${ }^{7}$

Powell's performance at the United Nations highlights one of the key reasons we need to rediscover methods appropriate to the arts and humanities. He expressly denied the need to interpret his pictures or audio grabs of intercepted phone calls. Instead he claimed they allowed unmediated access to 'facts'. While Powell was staking a claim to unmediated factual knowledge, one of the greatest anti-war artworks of the twentieth century, a version of Picasso's Guernica in the foyer of the UN building, had been shrouded over. The reason given by the UN authorities was that a plain surface was more suitable for press conferences. A member of the Australian Parliament, Laurie Brereton, considered it more plausible that it was to avoid embarrassment to the United States, in having its Ambassador or Secretary of State being seen to promote war with Iraq 'against a backdrop depicting images of women and children and animals crying with horror and showing the suffering of war'. ${ }^{8}$

Denying the need to interpret sense data-grainy images or scratchy recordings-Powell advocated the simple perception of 'facts'. What we see is the truth, and it comes to us preinterpreted. We have direct access to facts. The shrouding of Guernica illustrated the subversive threat of art, of images. Guernica 'depicts' war in a very different way than Powell's slide show. It must be interpreted, and knowing the story behind it helps. Guernica communicates in a more honest, and perhaps more powerful way than Colin Powell did. Conflicts like this, between immediate access to 'facts' and the ethical interpretation of art or texts, are often seen to represent a distinction between the sciences and the humanities. Yet interpretation underlies any approach to knowledge.

Law, more than any other discipline, is based on interpretation. Hermeneutics is at its heart. Yet even law has succumbed to a sort of cultural cringe before the natural sciences, apologising for its arguments and recoiling from its representations. ${ }^{9}$ Despite the important contributions law made to western epistemology in renaissance times, there are now few scholars who recognise the value and broader relevance of forensic inquiry and legal interpretation and decision making. ${ }^{10}$ The fact-value distinction had its roots in the subtleties of jurisprudence, and yet is turned against the law in accusations that it is a 'fraud ... that obscures the truth'. ${ }^{11}$ Is there a form of truth appropriate to law?

To compare the truth or honesty of a work of art, literature or law with that of 'facts' or documentary images is to inquire into the processes of representation and interpretation that go

\footnotetext{
As above Latour at 18.

8 Brereton Laurie 2003. 'Shroud over Guernica' Sydney Morning Herald 5 February 2003. http://www.smh.com.au/articles/ 2003/02/05/1044318661158.html accessed 11 January 2011.

9 Sherwin Richard K. 'Law, Metaphysics and the New Iconoclasm' (2007) 11 Law Text Culture 70 -105.

10 Hampshire Stuart Innocence and Experience Harvard University Press Cambridge MA 1989 at 54; Shapiro Barbara J A Culture of Fact: England 1550 -1720 Cornell University Press Ithaca 2000 at 10-11; Toulmin Stephen The Uses of Argument Cambridge University Press Cambridge, UK 1964 at 7.

11 Evan Whitton 'The Law Report' ABC Radio National 15 July 1997. The Chief Justice at the time accepted that law's role was 'not to pursue the truth'. Mason Sir Anthony The Future of Adversarial Justice, paper presented at the 17th AIJA Annual Conference, Adelaide, 7 August 1999.
} 
into each. Gadamer reaches back across the enlightenment to rediscover a humanism which he traces from late Roman law to Vico, in the late baroque. It is characterised by an approach to the 'art and practice of law that is closer to the practical ideal of phronesis than the theoretical ideal of sophia'.12 It requires common sense, taste and judgment. Since the rupture of the methods of the human sciences and the arts from the natural sciences, under Kant's influence, it is necessary to rediscover the common ground of hermeneutics, so that all our faculties ${ }^{13}$ can be brought to the task of interpretation, to discover the truth that is appropriate to the arts, humanities and law.

Benjamin's contribution to ways of knowing deriving from the baroque involves a new appreciation of the role of the object, the body part and the corpse. ${ }^{14}$ Benjamin's is still an approach to epistemology-the 'Epistemo-Critical Prologue' to his book on baroque Trauerspiel (German tragic drama) is his most sophisticated methodological statement-but in its approach to redeeming the objects, to recombining things, and deciphering allegories it encompasses ontology as well. To truly know something we must resonate with it, and so breach that Cartesian and Kantian firewall between subject and object, the knower and the known. ${ }^{15}$ Our world is populated by objects as much as by people and, like the baroque stage littered with corpses and rapiers, or the Vanitas painting with its skull and books, it must be interpreted with a full appreciation of the power of objects, emblems and allegory.

These twentieth century rediscoveries of some older ways of knowing have reverberated also in feminist epistemology since the 1980s. The Cartesian subject-object distinction was interrupted by Kristeva's notion of the abject, whose only point in common with the object is its opposition to the 'I', a subject. ${ }^{16}$ Yet it poses a fundamental threat to the self in its uncanny resemblance. If the corpse on the baroque stage, like the flat-lining encephalogram of Kristeva's example, signifies death, the real, putrefying corpse indicates death, it points to it. ${ }^{17}$ This horror between subject and object, between self and its negation, calls forth the original repression of the abject, played out in religious, moral and legal codes. ${ }^{18}$ The religious crises of the baroque era witnessed a renegotiation of the abject, without ever resolving our 'most intimate and serious apocalypses'. ${ }^{19}$ That would require the completion ('achèvement') of religion through a 'demystification of Power' in all its social aspects: 'religious, moral, political and verbal'. ${ }^{20} \mathrm{I}$ will return, in the conclusion, to questions of demystification, critique of ideology and the overcoming of repression.

12 Gadamer Hans-Georg Truth and Method Continuum New York 1989 at 20.

13 I intend 'faculties' in the sense that Chaïm Perelman uses it here: 'People who argue do not address what we call 'faculties', such as intellect, emotion, or will; they address the whole person, but, depending on the circumstances, their arguments will seek different results and will use methods appropriate to the purpose of the discourse as well as to the audience to be influenced.' Quoted Tindale Christopher W Acts of Arguing: A Rhetorical Model of Argument State University of New York Press Albany 1999 at 4. It is an ironic and happy coincidence that in the present context it could also refer to the academic disciplinary boundaries.

14 Benjamin Walter The Origin of German Tragic Drama NLB London 1977 (1928) at 132-9, 218.

15 As above at 33-4.

16 Kristeva Julia Pouvoirs de l'horreur: Essai sur l'abjection Éditions du Seuil Paris 1980 at 9.

17 As above at 11 .

18 As above at 23, 247.

19 As above at 246.

20 As above at 247. 
In other advances in feminist epistemology, Christine Buci-Glucksmann's Baroque Reason highlights the baroque tropes that were central to Benjamin's methods, 'the Reason of the Other'. ${ }^{21}$ Linda Martín Alcoff bases her feminist and social epistemology on a reading of Gadamer's hermeneutics through the lens of the coherence theory of knowing. ${ }^{22}$ The common project here is the location of knowledge and the knower in a social space. Knowledge results from social activity, not passive reception. In common with Foucault, Martín Alcoff identifies knowledge with power, and champions 'subjugated knowledges': truth is 'a strategic intervention into current discursive power relations'. ${ }^{23}$ Underlying each of these readings is a rejection of the Cartesian 'dichotomy of knowing subject and known object', which Grosz sees at the root of our recent 'crisis of reason' which privileges 'the purely conceptual or mental over the corporeal'.24

\subsection{KEYWORD: Signature (NATURE AND SCIENCE)}

The new sciences of the renaissance paid particular attention to the evidence available in the natural world. Ficino held that earthly things are able 'to channel (condurre) divine power to the human realm, drawing them together by means of their similitude', their resemblance to significant celestial bodies. ${ }^{25}$ Paracelsus compiled a Compendium (op. post. 1567) of plants and their connections with parts of the body and their afflictions. In his Signatura Rerum, the 'signature of the thing', Paracelsus elaborated the idea that the appearance of a thing was a marker for its power or efficacy: plants have a direct link to the body parts they cure. Many of these visual associations can be found in the plants' botanical names: pulmonaria works on the lungs, uvularia on the throat, and palma christi on the hands. For Paracelsus this was an unmediated power, exercised directly by the thing and indicated through its appearance. The signatura is the link between the outer and visible aspect of the thing, such as a plant, and its inner, invisible nature. ${ }^{26}$ In the renaissance keyword of 'signature', the manifestation of a thing is the guarantee of its efficacy.

Astrology studied the heavens and, working from the appearances of the constellations and the ancient personifications of the planets, sought links with human affairs. The stars and planets, like Paracelsus' plants, exercised a certain unmediated power on Earth. The frescos from the early renaissance Palazzo Schifanoia in Ferrara illustrate the point. In twelve sets of three panels the top panel represents the dominant planet in the month depicted, while the bottom panel shows the main agricultural activities in that season, as well as other human activities under the influence of the heavens. There are twelve such sets of panels. The middle panels remained mysterious for centuries until, just one hundred years ago, Aby Warburg's research into Arabic sources of

21 Buci-Glucksmann Christine Baroque Reason: The Aesthetics of Modernity Sage London 1994 at 39.

22 Martín Alcoff Linda Real Knowing: New Versions of the Coherence Theory Cornell University Press Ithaca 1996 at 46-7.

23 As above at $148-9$.

24 Grosz Elizabeth 'Bodies and Knowledges: Feminism and the Crisis of Reason' in Alcoff Linda and Potter Elizabeth (eds) Feminist Epistemologies Routledge New York \& London 1993 p 187 at 187-89.

25 Bianchi Massimo Luigi Signatura rerum: Segni, magia e conoscenza da Paracelso a Leibniz. Edizioni dell'Ateneo Roma 1987 at 26.

26 As above at 28 and see plates 2-3, where Fabricius illustrates the resemblance between the plant and the body part it cures. 
renaissance astrology revealed them as 'decani', particular images of celestial bodies that played a part in human affairs. Warburg's careful decoding of renaissance art and allegory became a model for twentieth century art scholarship, influencing the German tradition of both Benjamin and Gadamer. He concluded that astrological power in the renaissance was 'a fetishism of names projected into the future', so that, for example, one born under the sign of Venus would have qualities corresponding to those of the mythological Venus: love and the simple pleasures of life. ${ }^{27}$

One small detail of the panels depicting March illustrates my theme of representation and the senses. Sense data—such as the appearance of a thing-was seen as a guarantee of the thing itself, of a fact. In the bottom panel depicting human activities, under a doorway labelled 'Justice', we see four of the five senses represented: by the eyes, an ear framed between two heads, a nose silhouetted against the doorway, and, below that, a hand. In this renaissance economy of representation, justice is dignified and guaranteed by association with such reliable and direct sensory testing of the real world. So in the fifteenth century there was seen to be a direct and reliable link between representation and reality. The discovery of perspective lent a guarantee of geometrical certainty to our representations of the world. This new science of perspective guaranteed the reliability of representation in paintings of landscapes and buildings, while the then respectable sciences of astrology and Paracelsian medicine confirmed these links. Law, as depicted in the Palazzo Schifanoia, required a true perception of the 'facts', relying on the senses.

\subsection{KEYWORD: INGANNO (THE BAROQUE)}

Foucault has termed the renaissance 'the age of resemblance', in reference to this innocent acceptance of the correspondence between the thing, its nature and our perceptions of it. By the seventeenth century this was overturned by the 'games' of the baroque era, 'whose powers of enchantment grow out of the new kinship between resemblance and illusion'. ${ }^{28}$ Baroque art and architecture abound in trompe l'ail and virtuoso displays of illusion. Games of perspective give the illusion of depth, flat ceilings appear to rise up to the heavens, marble is carved into voluptuous folds of fabric. ${ }^{29}$ Galluzzi has contrasted the 'scientific' painting of the renaissance, with its fascination with perspective, to the 'literary and rhetorical' painting of the baroque, with its memento mori and allegorical depictions of Vanitas. ${ }^{30}$ Foucault draws attention to the baroque's theatrical comic illusions and plays-within-a-play. ${ }^{31}$ Artworks ranging from the sculptures of

\footnotetext{
27 Warburg Aby Arte Italiana e astrologia internazionale nel Palazzo Schifanoja di Ferrara Abscondita Milano 2006 (1912) at 17. See also Agamben's attribution to Warburg of the discovery of the signature, as 'neither sign nor symbol'. Agamben Giorgio Signatura rerum: sul metodo Bollati Boringhieri Torino 2008 at 59.

28 Foucault Michel The Order of Things Random House New York 1994 at 51.

29 Examples can be found, respectively, in a chapel of Santa Cecilia in Trastevere where a marble bas relief no more than a couple of centimetres deep appears to recede into the distance, in the ceiling of Sant'Ignazio in Rome, and in numerous sculptures by Michelangelo as well as dozens of lesser known artists.

30 Galluzzi Francesco Il Barocco Newton \& Compton Roma 2005 at 37.

31 Above note 28 at 51
} 
fantastical creatures in the 'park of monsters' at Bomarzo in northern Lazio, to the castrati's arias in Vivaldi's operas seek to inspire a sense of 'meraviglia', wonderment at the evocation of the impossible.

The central keyword of the Italian baroque was inganno (Spanish engaño, French trompe): a trick, a sharp practice, an illusion, yes, but with a certain malicious intent, a delusion. It was born of the distrust and suspicion of the senses that arose at the beginning of the seventeenth century when, as Foucault points out:

thought ceases to move in the element of resemblance. Similitude is no longer the form of knowledge but rather the occasion of error, the danger to which one exposes oneself when one does not examine the obscure region of confusions. ${ }^{32}$

Among the three possible sources of the word 'barocco', in addition to the conventionally accepted 'misshapen pearl', is a medieval term for a sharp commercial practice, an 'inganno economico e commerciale' that came to refer to the devious tricks of card sharps. ${ }^{33}$

Inganno is clearly untrustworthy and misleading; it can ensnare us in its net, by which it is identified in Ripa's book of iconology. ${ }^{34}$ Yet the artists and architects of the baroque loved to play with illusion. This was intended to go beyond the moral homily, that motivated the Vanitas paintings for example, to say something about representation as such. In addition to commenting on the unreliability of the senses, it is also a means of demonstrating human intervention and creativity in representation. Humanity can meddle with the presentation of sensory experience to make something appear in a totally new way. The words of a Vivaldi aria invoke storms at sea as a means of inducing powerful and turbulent emotions in the audience. The staging and the architecture of the baroque were constantly experimenting with these illusions and trompe l'œil. They called attention to the inganno, or trompe, at the same time using it to emphasise that the world is open to interpretation and that these representations could be effective as a source of meraviglia, knowledge and even power. Powerful images are no longer just those presented by nature, but they include human artefacts. The baroque has cast doubt on the unmediated efficacy of natural objects, driven by their appearance, and has started to explore the tricks and games by which we are deluded. This brings our own, human-produced images into the frame. And now we enter a new phase of the games of representation: how society, law and the powerful themselves intervene in the civil world through images and delusions.

As above at 51 .

Above note 30 at 20.

34 Leone Massimo 'Rete: la metafora e lo strumento. La democrazia e i suoi attori, il controllo e le libertà ' (2002) Golem l'indispensabile; Ripa Cesare Iconologia Neri Pozza Vicenza 2000 (1618). 


\subsection{REPRESENTATION AND EFFICACY IN HUMAN AFFAIRS}

Following the Council of Trent in the mid to late sixteenth century, art and other forms of propaganda were enlisted in the battle against the Protestant reformation. The new approaches to representation and practices of political theology and Tridentine propaganda went hand in hand with a raised awareness of the socio-political power of art and of objects. The seventeenth century witnessed high levels of games and of serious social contests carried out at the level of representation. The arts and literature of the time explored both the theory and practice of representation and interpretation, amounting to 'a convergence of political and philosophical experiments with visual and artistic ones'. ${ }^{35}$

The very concept of representation itself underwent important developments in this period. ${ }^{36}$ Hobbes' Leviathan was an important argument for the sovereign as representative of the people, which was powerfully reinforced by the image on the frontispiece (1651), where the huge sovereign coming over the hill is made up of hundreds of tiny people. The sovereign 'stands for' the people in a symbolic sense which is reproduced descriptively in the engraving. The image has its own power.

One of the key works of baroque drama is the Spanish play La Vida es Sueño (Life is a Dream, 1673) by Calderón de la Barca. The theme of the play is summed up in the often quoted last two lines of the hero Segismundo's soliloquy, which give the play its title:

... toda la vida es sueño,

y los sueños, sueños son.

Of greater interest, however, are three lines at the beginning of that soliloquy:

Sueña el rey que es rey, y vive

con este engaño mandando,

disponiendo y gobernando

The king dreams he is king, and lives

with this delusion ordering,

decreeing and governing ... ${ }^{37}$

All human relations, and the human condition itself, are no more than a dream. The king only dreams his sovereignty, just as the poor man dreams his misery. Yet this passage draws attention

35 Gamboni Dario 'Composing the Body Politic: Composite Images and Political Representation, 1651 -2004' in Latour Bruno and Weibel Peter (eds) Making Things Public -Atmospheres of Democracy ZKM and MIT Press Karlsruhe and Cambridge MA 2005 162-195 at 163. In connection with the religious conflicts of the seventeenth century I could also mention the importance of contested interpretations of the Bible, re-created as an object of wide consumption by the printing press. Calvo Serraller F. 'Rennaissance to Baroque' in Comadira Narcís (eds) La paraula figurada. La presència del llibre a les col.lections del MNAC Museu Nacional d'Art de Catalunya (MNAC) Barcelona 2005. The interpretation of a text was thus problematised, just as nature, art and devices were.

36 Pitkin Hanna Fenichel The Concept of Representation University of California Press Berkeley, CA 1972

37 Calderón de la Barca Pedro La vida es sueño Editorial Castalia Madrid 1984 (1673) at 162-3 (lines 2186-7 and 2158-60). 
to the social power of these dreams: dream as it may be, the king governs with this engaño. This 'with' may be seen as something the king just has to live with, like someone 'living with AIDS', but it should also be seen in an instrumental sense: the king orders, decrees and governs 'con este engaño': by means of this delusion.

Not only images but also other objects took on immense social and political power, seen both in arts and in the civic affairs of religion and politics. This was expressed in baroque theatre, where, as Benjamin points out, stage props became players in the action, often as the instruments of fate: he gives the example of the rapier in Hamlet. ${ }^{38}$ Corpses and body parts, too, could play effective roles, in some ways more effective than live humans, who tended more to be buffeted by fate than to be masters of it. Benjamin quotes a late seventeenth century source: 'The whole human body cannot enter a symbolical icon, but it is not inappropriate for part of the body to constitute it'. ${ }^{39}$ We may think here of the medieval and continuing Catholic cult of the relics of saints, which is also reflected in the Trauerspiel studied by Benjamin: 'martyrdom prepares the body of the living person for emblematic purposes. ${ }^{40}$

As the body part represents and instantiates the power of the saint, metonymy became part of the new baroque political theology: the crown makes (or is) the king. ${ }^{41}$ Buci-Glucksmann describes the severed head as 'a kind of figuration of desire, a trope in the precise sense' of designating something that has no name. ${ }^{42}$ Objects and symbols had, since at least medieval times, been understood to invoke power. Before the baroque this had been a divine power, or the power of nature: the relic, crown, sceptre, constellation or medicinal plant. The baroque now understood this power as something that was effective for political purposes, and could be studied, invoked, ridiculed and manipulated for those purposes, at once deceptive and effective. Recognising the power of representation as a human artefact, and not simply a reflection of nature, opens the way to its conscious political use. Tropes and emblems are instances of this new economy of representation, self conscious and critical. These images and artifacts are recognised as human products yet are still capable of calling forth mysterious powers.

\subsection{A NEW SCIENCE}

We find another allegorical emblem towards the end of the baroque period, in 1730, in the frontispiece to Giambattista Vico's New Science, which begins with a lengthy 'explanation' of the picture. A woman with winged temples is 'metaphysic', or the new science itself. The jewel on her breast is illuminated by God through his providence. She contemplates God in an attitude of ecstasy' at a higher level than the world of nature, which had been the concern of the

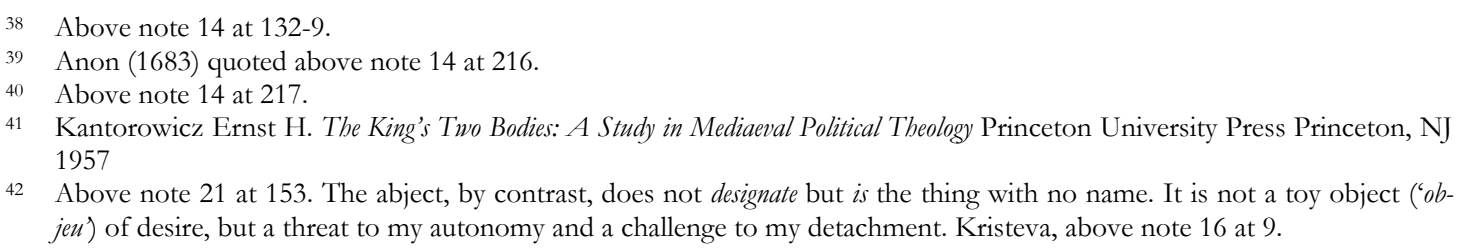

42 Above note 21 at 153 . The abject, by contrast, does not designate but is the thing with no name. It is not a toy object ('objeu') of desire, but a threat to my autonomy and a challenge to my detachment. Kristeva, above note 16 at 9. 
philosophers up to that time. Vico's science 'contemplates in God the world of human minds ... to show His providence in ... the civil world or world of nations'. ${ }^{43}$ The human institutions of writing, cultivation, navigation, music, commerce, law and government are represented by various objects or 'hieroglyphs' on the ground: the scales of justice, a rudder, text. The imbalance of the philosophers' hitherto focus on the natural world, to the exclusion of the world of human institutions and culture, is signified by the globe of the natural world being only half supported by the altar. Later in the book, Vico writes of 'the never failing light of a truth beyond all question':

$[T]$ he world of civil society has certainly been made by men so that its principles can and must be discovered within the modifications of our own human mind. Whoever reflects on this cannot but marvel that the philosophers should have bent all their energies to the study of the world of nature, which, since God made it, He alone knows; and that they should have neglected the study of the world of nations, or civil world, which since men have made it, men could come to know. ${ }^{44}$

This is not a detached study that absorbs all knowledge into itself: the jewel on the woman's breast refracts the light outwards again, to illuminate 'public moral institutions'. Again Vico draws the contrast with prior philosophy, in a passage redolent of Marx's, that the philosophers have missed the point, which is to 'change' or act in the world. Vico's new science, then, is a study of culture, law and human institutions that analyses myth, history and philology in order to seek an empathetic understanding of and through other human minds. It is a public and moral science, a 'philosophy of authority' that seeks to act back into the social and political world. ${ }^{45}$

Let's take stock, now, of this overview of the baroque's new approach to knowledge and representation, before moving on to see how it was submerged in the enlightenment before being rediscovered in the twentieth century. The renaissance had taken very seriously the appearances or manifestations of the natural world, whether of plants or planets. It studied such objects to gain insight into their efficacy, their force in the world. The baroque questioned such literal acceptance of the evidence of our senses: not only might sense perception be unreliable, it may also offer a means by which we are tricked or deceived. The political theology of representation was present everywhere, from the cities to the theatres, the churches to the courts. In each of these stage-like settings (mise-en-scène, palcosceni) the power of objects became their social power. The analysis of appearances could shift from the natural world to the social, to comprehend culture and its political ramifications. The edge was blurred between knowing and doing, between epistemology and ontology. We could now interpret the social world as our own products, in linguistic and visual terms.

These were the lessons of the baroque that had been the subject of plays, paintings and emblems, and that were distilled into a 'study method' by Vico. ${ }^{46}$ And yet these lessons were

43 Vico Giambattista The New Science Cornell University Press Ithaca, NY 1968 (1744) at 3.

44 As above at 96, translation modified by reference to Vico Giambattista La Scienza Nuova Rizzoli Milano 2004 (1730) at 232.

45 Above note 43 at $5-6$.

46 Vico Giambattista 'Il metodo degli studi del nostro tempo' in Opere Casa Editrice Fulvio Rossi Napoli 1972 (1709) p 121 
submerged by other approaches to knowledge and the sciences that led to the contemporary malaise that I described at the beginning of this article. They are the lessons that we need to relearn from the baroque. Before describing how they were rediscovered in the twentieth century, it is important to understand what went wrong. What interrupted our self awareness of the arts and civic institutions? To ask such a question is to go to the heart of law and the humanities, studies based squarely in that self awareness.

The period between the baroque and the twentieth century was dominated by a 'metaphysic' or science very different to Vico's. Bacon and Descartes stand at the beginning of this new history of science. Both were baroque figures in their own ways, yet they led science into new directions. Bacon shared the baroque suspicion of the senses: his famous doctrine of the idols that beset thought included one reminiscent of the inganno that ensnares us. The error of believing that things were connected by their resemblances was the 'idol of the tribe'. ${ }^{47}$ Descartes' mind-body dualism was typical of the baroque, ${ }^{48}$ as was his mistrust of the spontaneous evidence of the senses. To overcome the latter he proposed measurement and order, to calibrate difference and identity. ${ }^{49}$

This gap between the conceptions of our mind and the natural world had to be overcome in order to establish a reliable empirical science, a science of the 'outside' world. Kant provided the solution. Science can develop adequate conceptions of things, to which the phenomena conform. ${ }^{50}$ Representations no longer attempt a resemblance of the physical world, which can be so deceptive, as baroque art had demonstrated. Instead, the phenomena conform to our a priori representations, so the thought precedes the phenomenon. This is a Vichian effort: what we know is a product of our own mind. But unlike Vico, who confined his study to the social world, already a creature of the human mind, Kant declared a reliable link to the empirical, 'outside' world. All our measuring devices are directed towards testing the reliability of the connection between our conceptions or representations and the observed phenomena. Physics became the 'queen of the sciences' and scientific laws of observable nature became the dominant way of knowing. Facts were immediately apparent to the mind and had to correspond with the phenomena.

\subsection{DiverGENCE OF THE ARTS: SYMBOL AND ALLEGORY}

But if our conceptions are all objectively reliable and verifiable representations of an outside world, where does that leave art and the humanities? Having done such a good job, in the baroque, of discrediting sense experience, art was now to pay the price. Kant took on that

\footnotetext{
47 Bacon Francis The New Organon and Related Writings Bobbs-Merrill Indianapolis 1960 (1620) at 50-53, especially \$LI. See also Foucault, above note 28 at 52.

48 Above note 14 at 217.

49 Above note 28 at 52.

50 Kant Immanuel Critique of Pure Reason J. M. Dent \& Sons London 1934 at 12.
} 
challenge as well, and relegated the aesthetic to the realm of the subjective, as Gadamer has explained:

The radical subjectivization involved in Kant's new way of grounding aesthetics was truly epoch-making. In discrediting any kind of theoretical knowledge except that of natural science, it compelled the human sciences to rely on the methodology of the natural sciences in conceptualizing themselves. But it made this reliance easier by offering the "artistic element", "feeling", and "empathy" as subsidiary elements. ${ }^{51}$

If science was now about the objective apprehension of phenomena that guaranteed the 'facts', art took the opposite direction. Taste became subjective, and the romantic conception of inexplicable genius could develop. Art was to be understood as raw experience (Erlebniskunst), and not a foundation for analysis, critique and interpretation. The romantic appreciation of art is all in our feelings: if our objective conceptions can lead to natural science through reliable correspondence to reality, our subjective tastes lead us to swoon before beauty. Whether we are confronting natural or artistic beauty, the response was to be subjective, unshared, overwhelming experience.

Gadamer and Benjamin led the twentieth century's efforts to rethink this obscurantist dilemma (both in the arts and the human sciences) by going back to the baroque allegory. They rethought the economy of representation by reclaiming the allegory as a way of knowing. In the post-Kantian romantic era, the symbol became the dominant form of representation. The symbol's meaning is immediately apparent: it inheres in the form. Exhibiting a badge of identity-a templar's cross, a national flag or a corporate logo-forms an instant association with the group to which we belong. ${ }^{52}$ Benjamin referred to this as the 'paradox of the theological symbol': the material symbol and the abstraction for which it stands are collapsed into a single unity of appearance and essence. ${ }^{53}$ The symbol is taken in at a glance: we either get it or we don't. Expressed in symbolist art that flourished in the late nineteenth century, the image releases a charge of emotions which are presumed to reverberate instantly in the viewer. ${ }^{54}$

The allegory, on the other hand, must be read. It presumes a lexicon of meanings that are based in tradition, in a long-running social context. Its interpretation is not subjective, depending on the artist or the viewer to bring their own genius to it. An interpretation can be more or less accurate, better connected to the tradition from which it springs, more or less rich in understanding. This is what Gadamer means by 'truth in art'. Through it we can overcome the fragmented subjectivism of individual takes on a single work so that art may fulfill its role in 'the task of preserving the hermeneutic continuity which constitutes our being. ${ }^{5}{ }^{5}$

\footnotetext{
Above note 12 at 41 .

As above at $72-3$.

Above note 14 at 160 .

54 See, for example, Dreams of Nature: Symbolism from Van Gogh to Kandinsky, Van Gogh Museum, Amsterdam, AprilJune 2012, with a catalogue by Rodolphe Rapetti, Richard Thomson, Frances Fowle and Anna-Maria von Bonsdorff. See also http://www.vangoghmuseum.nl/vgm/index.jsp?page=252284\&lang=en accessed 21 May 2012.

55 Above note 12 at 96.
} 
The groundwork for this new appreciation of meaning and interpretation had been laid by an important group of German art historians inspired particularly by Aby Warburg, mentioned earlier, in the context of deciphering the meanings of the frescos in the Palazzo Schifanoia by tracing the influence of Arabic astrological writings on the artists and their circle. Both Benjamin and Gadamer looked back to the baroque as an age of allegory. Benjamin found in it a flourishing of meanings and their opposites that guided his esoteric explorations. For Gadamer, it was the last age in which the shared dogma of Europe was able to guide interpretation.

These divergent interests led to different issues for our own studies in law and the humanities. Gadamer sees allegory as a means of knowing, of finding truth. His intention is epistemological, an exercise in understanding, thinking and knowing (which, as Foucault notes, 'is always allegorical). ${ }^{56}$ But if it is no longer guided by a shared dogma, how are we to save hermeneutics from a hopeless partisanship in the contests of ideas? The critical edge of hermeneutics comes into play in this new era when, in Kristeva's terms, the old codes of religion and ideology no longer suffice to purify and repress the threatening abject. The allegorical memento mori or Vanitas painting signifies death in a stylised manner, as food for thought. The symbolist painting comes to the fore in an era when religious feeling is reduced to psychology and emotion, 'shivers and goosebumps' in Agamben's terms. ${ }^{57}$ The repressed returns with the twentieth century's 'great demystification of power'. ${ }^{58}$ Freud's critique of repression, or Marx's critique of ideology, give rise to an alternative hermeneutics of suspicion, more critical than Gadamer's 'hermeneutics of tradition' and its close reading of the dogmas and meanings in which a text or image is rooted. I return in section 9.0 of this article to this distinction and the ways it, too, draws on the baroque. First, I will address some key questions opened up by Benjamin's interest in the power of things and in their links to ideas. In each of these concluding sections we may see different areas of relevance to contemporary problems, which are both methodological and practical: they concern the 'study methods of our time', as Vico put it, and they also illuminate the contradictions that were performed at the United Nations on February 5th 2003. These conclusions are organised into sections that revisit the two keywords with which I began: signatura and inganno.

\subsection{Signature 2 ('The Performative)}

The power of things has been rediscovered anew since Benjamin's work on the baroque. From Austin's performative to Latour's actor network theory, the past half century has seen wellknown explorations of the role played by objects and signs in the social world. ${ }^{59}$ Of particular importance to law have been the explorations of the signature, as a reiterated performative

\footnotetext{
56 'L'analyse de la pensée est toujours allégorique.' (emphasis in original) Foucault Michel L'archéologie du savoir Gallimard Paris 1969 at 42.

57 Agamben Giorgio Homo Sacer: Sovereign Power and Bare Life Stanford University Press Stanford, CA 1998 at 78.

58 Above note 16 at 247.

59 Austin J. L. How To Do Things With Words Oxford University Press Oxford 1980; Latour, above note 6.
} 
gesture, by Derrida and Butler. ${ }^{60}$ Before further consideration of that work, I would like to explore, though Benjamin, the links and differences between the renaissance notion of the signature and the phenomenon so central to current studies of law. Benjamin's interest in the power of things links the ontological and the epistemological. Benjamin sought not to match phenomena to existing mental concepts but to redeem them, so that they could 'participate in the existence of ideas', by representing them. ${ }^{61}$ This is by no means Kant's one-to-one fit between the concept and the phenomenon, but a dialectical process. In the manner of allegories, ideas are built up, put into practice, and recalled by their associations with things. That leads us to question how it is that objects and representations can enter into civic life and can change the social world.

Law is one of the formal, recognised ways in which the social world-or the civic order-is definitively changed. Yet the means by which this could be done have been increasingly challenged by sceptical views of law. The force of law moves from being an article of faith to an intellectual problem: one solution involves the power of objects. Law relies on material manifestations for its records and proofs. Files, evidence, documents and signatures are the repository of law's memory. Benjamin indicated the persistence of objects as the guarantee of loyalty: 'every loyal vow or memory surrounds itself with the fragments of the world of things as its very own, not-too-demanding objects.'62

In changing the social world, the performative act of making a vow or taking an oath requires a permanent trace. Unlike other speech acts that just describe the world, the performative utterance brings something into existence. If renaissance science was wrong to see the power or efficacy of natural objects in the pure manifestation of their appearance, we might still redeem this insight for the human sciences. The study of the performative leads us to see that in the English word itself, a 'signature' is something that has efficacy through its appearance. If I sign a document such as a contract or a cheque, I have created a binding relationship that affects me and others. This new relationship brings something into being in the social matrix that did not exist before.

Derrida contributed the insight that the performative act, including the signature, must be a repetitive ritual; that it partakes of a system of social power, which can even be subverted. ${ }^{63}$ Butler further developed the notion that the very power inherent in the repeated citation of a performative formula can also be turned back on, or more subtlely remake the political or legal order.

Thus, performativity has its own social temporality in which it remains enabled precisely by the contexts from which it breaks. This ambivalent structure at the heart of performativity

\footnotetext{
60 Butler Judith Bodies That Matter: On the Discursive Limits of "Sex" Routledge New York 1993; Derrida Jacques Limited Inc Northwestern University Press Evanston IL 1988

61 Above note 14 at 33-4.

62 As above at 157.

63 Derrida above note 60 at $18,133$.
} 
implies that, within political discourse, the very terms of resistance and insurgency are spawned in part by the powers they oppose....64

The insight that a sign or a mark can be effective by being revealed may have led to a dead end in the natural sciences. God did not, after all, sign His works so they might guide us. However, when this idea is refracted into the social sciences, using the principles discovered by Vico, it leads to important insights. While scientists looking for manifest signs in the natural world lacked a viable research program, the examination of Vico's 'world of civil society', that we ourselves have made, reveals that we can understand our own actions and their effects in that world. The study of the marks made by people, whether these be signatures or works of art, is open to interpretations through various means: semiotics, discourse analysis, hermeneutics or iconology. That these marks and objects do not only describe the world, but also make and remake it, is a characteristic insight of the baroque which was rediscovered in the twentieth century. ${ }^{65}$ Subsequent work revealed that these mechanisms of political power can themselves be an instrument of social change or subversion. These developments bring to the practices of the arts and law the scholarship they deserve.

\subsection{INGANNO 2 (HERMENEUTICS )}

That these signs may sometimes deceive us is another powerful insight of the baroque. If signs and communications are used for social regulation, then it is important to have means for evaluating and criticising those constraints. The baroque games of inganno and trompe l'œil rehearsed in art the lessons that were explored by scholars and critics of law and civil society, from Calderón to Vico.

Iconoclasm-suspicion of idols and fetishes-has a long history in the Abrahamic religions.

Iconoclasm has a history at least as old as idolatry. ... Indeed, one might argue that iconoclasm is simply the obverse of idolatry, that it is nothing more than idolatry turned outward toward the image of a rival, threatening tribe. ${ }^{66}$

What was novel in the baroque was the playful exploration of appearance and illusion, and the political and philosophical critique of the relationship between the two. Gadamer revives an interest in games as a methodology: in this he follows Huizinga and was followed by Derrida. ${ }^{67}$ They open up a world of possibilities, remove a fourth wall, so that play comes into focus as both

64 Butler Judith Excitable Speech: A Politics of the Performative Routledge New York 1997 at 40.

65 Austin above note 59; Benveniste Emile Problèmes de linguistique générale Gallimard Paris 1966 at 265; Foucault above note 56 at $119-21$.

66 Mitchell W. J. T. Iconology: Image, Text, Ideology University of Chicago Press Chicago 1986 at 198.

67 Above note 12 at 103-09; Huizinga Johan Homo Ludens. A Study of the Play Element in Culture Beacon Press Boston 1952; Derrida above note 60 at 18; Derrida Jacques Writing and Difference University of Chicago Press Chicago 1978 at 292. These authors use 'play' in all its senses: the play in a loose rope, child's play, and a dramatic work. Their work illustrates the connections between those senses. 
an aspect of interpretation and a component of social and legal communication. Gadamer distinguishes the 'abundance of viewpoints' this affords from the serious critique of ideology (another manifestation of iconoclasm). He finds it 'frighteningly unreal when people like Habermas ascribe to rhetoric a compulsory quality that one must reject in favor of unconstrained, rational dialogue'. ${ }^{68}$ Ricœur has characterised this dispute between Gadamer and Habermas as the contest between a 'hermeneutics of tradition', based on 'reminiscence' and one based on 'suspicion'. ${ }^{69}$ While defending Gadamer's appeals to tradition, Ricœur proposes, in juxtaposition, a critical hermeneutics, that sees the role of power relations in distortion and delusion. The negation of recognition (connaissance) of the other, of communication, is misrecognition (méconnaissance),${ }^{70}$ which is ' peculiar to the problem of ideology.'

It can be analysed phenomenologically only by appealing to concepts of a psychoanalytic type: to illusion as distinct from error, to projection as constitution of a false transcendence, to rationalisation as the subsequent rearrangement of motivations according to the appearance of a rational justification. ${ }^{71}$

The systematically distorted communication of ideology, in Habermas's terms, can thus be best understood through psychoanalysis. In repression and in hegemonic domination we are overwhelmed by the burden of past events and distorted thoughts and communications. We can be dominated by ideas, images, dreams and objects. As in Calderón's kingdom, we too are ruled by engaños, by these dreams of our rulers.

The insights of the baroque, and an appreciation of its earnest games, allow an approach to interpretation that does not seek a binary distinction between the one truth and the many falsehoods, but which explores the foundations of our illusions. It is only by reviewing our illusions, and reinterpreting our dreams, that we can seek new knowledge, 'mak[ing] it possible to incorporate our intuitions within an account of real knowing. ${ }^{72}$ If it is a task of the human sciences to discover meaning through hermeneutics, it is also our task to interrogate the excesses of meaning in those objects, acts, or utterances that make and remake our social world. Where we discover this disconnect between the signified and the signifier, so that a symbol, myth or performative has an aura of excess meanings beyond its literal reference, we must ask not only what it means but what it does..$^{73}$ To do this we can draw on a hermeneutics of suspicion and of tradition, while remembering the games of the baroque, that are always so good at revealing deception even as they deceive us.

\footnotetext{
Above note 12 at 568 .

Ricœur Paul Hermeneutics and the Human Sciences Cambridge University Press Cambridge 1981 at 34, 83.

Ricœur Paul Parcours de la reconnaissance: Trois études Gallimard Paris 2004 at 397.

Above note 69 at 84 .

Above note 22 at 212 .

Mohr Richard 'Living Legal Fictions: constituting the state or submerging the signifier?' (2006) 193 International Journal for the Semiotics of Law 237 at 240-1.
} 


\subsection{CONCLUSION}

This inquiry began by highlighting the contemporary malaise which has seen law cut off from the humanities and cringing before a deracinated, positivist account of the dominant natural sciences. Law, the discipline that introduced the term 'fact' (fait, fatto)—what has been done-and modelled a new conception of laws of nature to explain those facts, was reduced to doubting its truths. In tracing a history that parallels the demise of law's primacy as a method of knowing and deciding, we have seen that faith in law as a code gave way to doubt of law as an instrument of social power. Out of these doubts arose new methods, new understandings and, as I have been advocating here, new relevance for law's affinities with the arts and humanities. A new world of inquiry and critique opened up once 'the force of law' became a problem to be solved, rather than a faith to be defended.

Two rather ambitious questions led the charge: how do we know? and how do we live (together)? I cannot claim to have answered them, but their respective epistemological and ontological fields suggest points of reference for a summary of conclusions. These questions are connected by the common problem of the split between a knowing and doing subject and a passive, known object. Instead of stripping away our subjectivity to an inhuman object-ivity, the reunification of knowing and being can be better achieved by recognising the power of objects and the conditions of power over subjects.

Objects, images and representations incorporate social power. They are coded or invested with meanings that function to remind us of certain social facts. Legal documents, the trappings of power, items of evidence: they remember for us. The renaissance belief in the signature of the thing turned out to be an unreliable indicator of God's intention, but a valuable clue to social relations. Like any memories, those coded into objects are selective and open to reinterpretation. Indeed, they are re-remembered and subtlely changed with every recollection, invocation or iteration. Their power is not over-determined but is contingent on the performance of each new iteration, whether it be loyal and faithful or insurgent.

Baroque demonstrations of the unreliability of the senses led to games of illusion. These games stimulated the playwrights and philosophers to wonder how deep they ran in social and political life. Life, for Calderón, was a dream. Just as dreams can be more or less life-like, can be interpreted this way or that, so representations can be recognised in many guises. In fact, in their guise as dreams and illusions, they can be misrecognised (méconnu), to use Ricœur's terminology. That is to say, they can be vehicles for rationalisation and repression. Legal and religious codes and practices provide ample material for rationalisation and for analysis, from their imagery to their narratives, their theories and theologies. Even the naïve positivism born of half-understood notions of science and empiricism provide backing for imperialist efforts to justify war on the basis of purportedly uninterpreted 'facts'. Through the conflicts of the reformation and the counter-reformation that enlisted and formed the baroque's sensibilities, the 'shared dogma' of the west was shaken to its core. That first awakening from the 'sleep' of dominant religious and legal codes prepared the way for the 'great demystification of Power', the return of the repressed 
that was opened up in the twentieth century. ${ }^{74}$ The insights of ideology critique and psychoanalysis added a critical edge to the new developments in methods based in hermeneutics and the performative.

The truth in law, as in the arts and humanities, is a deep and complex construction built of representations and their interpretation. This interpretation is not just subjective, but intersubjective. It is not the immediate experience of the sublime, the swoon before beauty, or the uncritical acceptance of preinterpreted facts. ${ }^{75}$ It is built up from prior understanding, interrogation of the subject matter, comprehension of the motivations of other people, people like us. For this it needs a hermeneutics based in tradition and memory. Yet if we are not to be deluded by the preferred interpretations of the people with power, and the deceptions of those determined to cling to it, we can find truth in unexpected places: the slip of the tongue, the repressed memory uncovered in an old ritual or image, dreams of domination.

74 Above note 16 at $246-7$.

75 Here 'facts' is written without the quote marks since it is used, without apology, in the legal sense: the accounts of deeds that are always open to scrutiny, interpretation and reinterpretation. 